\title{
Anniversary Issue Editorial
}

\author{
MATTHE F F A N , PIER S L U L OW \\ A N D JESSICA REINISCH
}

This issue opens the twenty-fifth volume of Contemporary European History. In the journal's inaugural editorial in I992, Kathleen Burk and Dick Geary noted that they were standing 'on the brink of a new Europe' ${ }^{1}$ - and what exciting times those were. Just two and a half years after the collapse of the Berlin Wall, and barely months after the formal dissolution of the Soviet Union, CEH came into existence at a time of radical change in Europe and beyond. With the treaties signed at Maastricht in 1992 and in Amsterdam in 1997 European integration accelerated apace. The European Community became a Union. The twelve became fifteen. From March I995 the Schengen Agreement let people of any nationality travel freely between the seven participating countries without any passport controls at the borders. By the end of the decade, the Single Market was a reality, the Euro was about to be introduced and negotiations for EU membership of ten central and eastern European countries were well underway. The themes of the decade were (re)integration, federation, ever greater union. As Burk and Geary wrote in their 1992 editorial, 'year by year, the concept of Europe as both a geographical and an historical entity becomes more credible'. $^{2}$

It was a good time to challenge a number of prevalent historiographical assumptions and premises. In hindsight, two of these challenges in the new journal's manifesto were particularly striking. First, at the end of the Cold War, the differences between pre- and post-war Europe no longer appeared to be as stark as many scholars had assumed. I945 was no zero hour. One of CEH's explicit aims was to shed light on the continuities across the century and to develop comparisons between the two post-war eras. Second, $C E H$ was to provide a forum for overcoming the many splits and divisions in the historiography of twentieth century Europe, which consigned research into geographically, politically and methodologically restricted

\footnotetext{
1 Kathleen Burk and Dick Geary, 'Editorial', Contemporary European History, I, I, (I992), i. ${ }^{2}$ Ibid.
} 
boxes. To counter this trend, $C E H$ was conceived as a journal where the histories of the Eastern and Western blocs, and those of individual European states - small and large, and including the United Kingdom - could be studied side by side, even in comparison, and through the lenses of any particular school of history. In both these aims, the original editors hoped the journal would become a means for overcoming historians' insularity - insularity within their national communities, their disciplinary branches and their particular chronological ranges.

The world looks rather different in 20I6. Today's news is no longer dominated by excitement about growing European integration and expansion, but by antiEuropean protests and the electoral successes of anti-European parties, the threat (and reality) of expulsion of member states from the EU and the possible end of Schengen, as the EU lurches from one crisis to the next. Hope and optimism about the end of the Cold War have given way to a kind of frustrated recognition of the complexity and heterogeneity of global political, economic and social alliances and confrontations. Nonetheless, the journal's agenda as conceived by Burk and Geary is as relevant now as it was in I992, perhaps even more so. Today it is still far from commonplace that Eastern and Western European histories are considered in the same frame of analysis; the old Cold War paradigm about the incomparability and incompatibility of the former Cold War blocs continues to hold subtle but lasting sway. $C E H$ continues to challenge this paradigm and publish scholarship on 'European history in its widest sense'. ${ }^{3}$

The challenges of overcoming national and disciplinary insularity remain, but each has subtly changed since I992. There has been some movement away from the isolated silos of national histories that once prevailed. The rise of transnationalism as both a subject matter and a historical approach (a particular focus of the journal in previous and forthcoming issues), the growing interest in cross-cutting themes such as European integration history or identity politics in Europe's borderlands and the ever-greater mobility of research students and academics themselves have all helped French history or Hungarian history, Sweden's past or that of Poland, become slightly less restricted zones. The days when it was safe to assume that the senior German professor must be a specialist in Germany history, or that the young Spanish research student must be at work on an Iberian-centred topic, are long behind us. Important too has been the ceaseless rise of English as an academic lingua franca, with the knock-on effect that many more academics whose first language is not English feel that publishing their research in an Anglophone journal is a rite of passage of value and importance to their careers and reputations. At the same time, the journal continues to feature multi-lingual abstracts, accept submissions in languages other than English and provide resources for translating outstanding articles into English.

Such developments boost rather than diminish the value of a journal that aspires to cover the full diversity of national and international histories of contemporary Europe. Contemporary European History is proud of the extent to which it has become

3 Ibid. ii. 
a key outlet for historians based across Europe (and increasingly in the United States) who want to make their research findings accessible to an English-speaking audience. Over the last twelve months alone we have published articles by researchers based in thirteen different European university systems. Bridging the gap that has sometimes arisen between debate about European history within Europe, and that which occurs amongst Europeanists working outside of Europe, especially in North America, has been another important challenge. It was for this reason that $\mathrm{CEH}$ has in recent years engaged both an editor and a reviews-editor based in the United States. Recent improvements in the way in which the journal is run will hopefully ensure that Dominique Reill and Emily Greble - our current US-based colleagues - are now fully integrated into the direction and editorial choices of the journal.

The dangers of over-specialisation, meanwhile, have if anything grown rather than diminished since I992, as illustrated by the proliferation of specialist journals, conference circuits and networks devoted almost exclusively to one particular theme, approach or issue. This too is a trend that only underlines the importance of a journal that has sought to be open to almost any theme and school of modern European history. For it matters greatly that the researchers whose academic exchanges centre primarily on, say, the political history of I960s France and Italy also have an opportunity to stumble across and hopefully engage with pieces on gender politics in Scandinavia or interwar economic history in the Baltic region. Such out-ofarea encounters won't always leave an immediate mark, of course. It can be all too tempting to just read those articles within one's own narrow field. But even the brief scan of an abstract, or the half-recollection of the title of an article, may help jolt each of us out of our sub-disciplinary comfort zone. As a result, CEH is pleased to have served up a menu of original, ground-breaking research which in the course of the last year alone has included religious history and that of the media, pieces on fascism and on music, on human trafficking and on English language promotion, on Socialist internationalism and Hungarian-Slovakian borderlands, and a special issue on Urban Societies. The editors certainly feel that this huge thematic diversity of high quality research keeps us on our toes, constantly challenging us to locate the relevant specialists as peer reviewers and to gauge the relative quality and importance of such widely varying offerings. We very much hope that the journal's readership feels the same way. And we look forward to offering an ever greater range of articles, reviews, fora and special issues in the years and decades ahead. While the political landscape of contemporary Europe has altered dramatically since I992, the original values, mission and contribution of $\mathrm{CEH}$ remain fundamentally unchanged and relevant. 